\title{
Evaluation of the use of iodized salt by pregnant women and their knowledge on the use of iodized salt
}

\author{
Emine Özge Avcı' ${ }^{1}$, Bahtışen Kartal ${ }^{2}$, Evrim Bayraktar ${ }^{3}$ \\ ${ }^{1}$ Department of Nursing Services, Nev̧̧ehir State Hospital, Nevşsehir, Turkey \\ ${ }^{2}$ Department of Nursing, Faculty of Health Sciences, Tokat Gaziosmanpasa University, Tokat, Turkey \\ ${ }^{3}$ Department of Nursing, Faculty of Health Sciences, Erciyes University, Kayseri, Turkey
}

\begin{abstract}
Objective: The aim of our study is to evaluate the use of iodized salt by pregnant women and their knowledge on the use of iodized salt.

Methods: The study is of descriptive type. The sample of the study consisted of 347 pregnant women. The data of the study was collected by using a data form developed by researchers. The data obtained by the study was analyzed by means of SPSS package software.

Results: Of the pregnant women included in the study, the mean age was $27.38 \pm 6.44$ years old, $41.8 \%$ were living in urban areas, $34.6 \%$ were graduated from secondary school, $80.7 \%$ were housewives, $50.4 \%$ had income equal to their expenses, and $43.8 \%$ had husbands who were workers. It was found that $74.1 \%$ of the pregnant women had no knowledge on iodine deficiency and associated diseases, $35.7 \%$ of them did not know the importance of protection against iodine deficiency, and $65.7 \%$ of them did not know the necessity of using iodized salt during pregnancy. Also, we found that $44.1 \%$ of the pregnant women included in the study did not use iodized salt, $56.2 \%$ of those using iodized salt did not keep it in a proper way, and $16.7 \%$ of them added iodized salt into their meal after prepared. It was seen that $68.6 \%$ of the pregnant women did not receive information for the use of iodized salt during pregnancy.

Conclusion: In conclusion, we found that the use of iodized salt during pregnancy and knowledge on the use of iodized salt are insufficient. We can say that pregnant women need training on the use of iodized salt, the time for adding salt into meals and methods for preserving salt.
\end{abstract}

Keywords: Pregnancy, iodized salt, iodine insufficiency.

\section{Introduction}

Cardiovascular system (14.6\%) and endocrine system diseases $(14.5 \%)$ are the leading diseases threatening women's health. Thyroid gland diseases are the most

\section{Özet: Gebe kadınların iyotlu tuz kullanımının ve iyotlu tuz kullanımına ilişkin bilgilerinin belirlenmesi}

Amaç: Çalışma gebe kadınların iyotlu tuz kullanımını ve iyotlu tuz kullanımına ilişkin bilgilerini belirlemek amacıyla yapılmıştır.

Yöntem: Çalışma tanımlayıcı tiptedir. Çalışmanın örneklemini 347 gebe oluşturmuştur. Çalışmanın verileri araştırmacılar tarafindan geliştirilen bir veri formu kullanılarak toplanmıştır. Çalışmadan elde edilen veriler bilgisayar ortamında SPSS paket programında değerlendirilmiştir.

Bulgular: Gebelerin yaş ortalamasının 27.38 \pm 6.44 olduğu, \%41.8'inin ilde yaşadığ ${ }_{1}$, \%34.6'sının ortaokul mezunu, \% 80.7'sinin ev hanımı, \%50.4'ünün gelirinin giderine denk olduğu, \%43.8'inin eşinin işçi olduğu belirlenmiştir. Gebelerin \% 74.1'inin iyot yetersizliği ve hastalıkları hakkında bilgisinin olmadığı, \%35.7'sinin iyot eksikliğinden korunmanın önemini, \%65.7'sinin gebelikte iyotlu tuz kullanmanın gerekli olduğunu bilmediği belirlenmiştir. Ayrıca gebelerin \%44.1'inin iyotlu tuz kullanmadığı, iyotlu tuz kullanan gebelerin \%56.2'sinin iyotlu tuzu doğru saklamadığı, \%16.7'sinin tuzu yemeğe piştikten sonra ilave ettiği bulunmuştur. Gebelerin \%68.6'sı gebelikte iyotlu tuz kullanımına ilişkin bilgi almadığını belirtmiştir.

Sonuç: Sonuç olarak gebelikte iyotlu tuz kullanımının ve iyotlu tuz kullanımına ilişkin bilgilerin yetersiz olduğu belirlenmiştir. Gebelerin iyotlu tuz kullanımı, yemeğe tuz ilave etme zamanı ve tuzu muhafaza etme hakkında eğitime gereksinimi olduğu söylenebilir.

Anahtar sözcükler: Gebelik, iyotlu tuz, iyot yetersizliği.

common disorders among endocrine system diseases with a rate of $5.6 \% .^{[1]}$

Physiological changes during pregnancy affect the activities of thyroid gland. The incidence of hypothy-
Correspondence: Emine Özge Avc1, MD. Department of Nursing Services, Nevşehir State Hospital, Nevşehir, Turkey. e-mail: avciozge1@gmail.com

Received: July 2, 2018; Accepted: December 18, 2018

Please cite this article as: Avcı EÖ, Kartal B, Bayraktar E. Evaluation of the use of iodized salt by pregnant women and their knowledge on the use of iodized salt. Perinatal Journal 2018;26(3):141-147.

(C2018 Perinatal Medicine Foundation
Available online at: www.perinataljournal.com/20180263009 doi: 10.2399/prn.18.0263009 QR (Quick Response) Code:

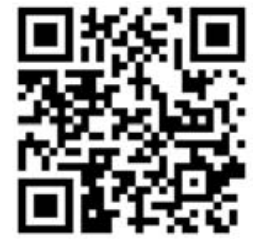


roidism during pregnancy is reported $2-3 \% .{ }^{[2]}$ However, the incidence of undiagnosed hypothyroidism and hyperthyroidism is higher. The rate of hypothyroidism during pregnancy is consistent with the literature in two studies performed in Turkey; ${ }^{[3,4]}$ however, Güzel et al. found it $15.8 \%$ in their studies. ${ }^{[5]}$ Hypothyroidism during pregnancy affects maternal and fetal health negatively. The most common reason for hypothyroidism is iodine deficiency. The synthesis of thyroid hormones depends on the penetration of sufficient amount of iodine into thyroid, normal iodine metabolism in the thyroid and normal thyroglobuline synthesis. ${ }^{[6]}$ Insufficient iodine intake may cause maternal hypothyroidism, insufficient fertilization, preeclampsia, postpartum hemorrhage, anemia, miscarriage risk, low birth weight, stillbirth, congenital anomalies, fetal neurological development disorders, microcephaly, cretinism and similar outcomes. ${ }^{[7-9]}$ It may also cause goiter and congenital hypothyroidism in the newborn..$^{[7-9]}$ It is reported that iodine deficiency is the most common reason for preventable mental retardation in the world. ${ }^{[10]}$ It is also reported that there is an increase in the mortality risk of newborns associated with the iodine deficiency. ${ }^{[1,12]}$ Congenital hypothyroidism is one of the most common endocrine diseases of newborns. ${ }^{[13]}$ Chronic thyroid hormone deficiency is seen in one per 3500-4000 newborns in the world and per 2525 children in Turkey. ${ }^{[14,15]}$

Iodine need increases during pregnancy and therefore iodine intake should be increased to meet increasing need. ${ }^{[2]}$ World Health Organization recommends 250 mcg of iodine intake daily for pregnant women. ${ }^{[16]}$ Urinary iodine, which is the best indicator for iodine level, should be $>100-200 \mathrm{mcg} / \mathrm{L}$ in pregnant women, and therefore it is recommended to take $250-300 \mathrm{mcg}$ iodine daily by means of iodized salt, sea products and iodine-rich foods. ${ }^{[2]}$ However, it is seen that mean daily iodine intake is $66.4 \mathrm{mcg}$ for pregnant women and 65.7 mcg for breastfeeding women in Turkey. ${ }^{[17]}$ It has been found in the studies performed in Turkey that pregnant women have iodine deficiency. ${ }^{[2,18-21]}$

In Turkey, iodine deficiency is an endemic problem in all regions and iodine deficiency is associated with the insufficient intake by diet. "The Program of Preventing Iodine Deficiency Diseases and Iodizing Salt" has been carried out since 1995 in Turkey to fight against iodine deficiency, and it has been made obligatory to iodize table salt by legal regulations as of 1998 in accordance with this program. Food industry salt is not iodized. It is highlighted that the iodine needs (200-250 mcg/day) of women planning pregnancy, pregnant women and breastfeeding women whose salt intake should be restricted due to various reasons should certainly be met. ${ }^{[17]}$

Although it has been 20 years for the obligatory iodization of salt, it is seen in various studies that iodine deficiency is still a risk for the health of mothers and children. This shows us that the process of iodizing salt is not sufficient alone to eliminate iodine deficiency, and that it is necessary to inform individuals / pregnant women about the use of iodized salt. It is considered that determining the use of iodized salt by pregnant women and their knowledge on the use of iodized salt in order to prevent thyroid dysfunctions associated with iodine insufficiency and to protect the health of mothers and newborns would guide the initiatives to be planned for identifying and resolving the problem.

\section{Methods}

The study is of descriptive type and it was conducted in the Maternity Clinic of Nevşehir State Hospital of Nevşehir Public Hospital Association. The sample of the study consisted of 3637 pregnant women who admitted to this hospital in a year. The sample size was calculated by using the method of sampling from known population.

As the number of individuals in the population is known, sample size was calculated by the following formula:

- $\mathrm{n}=\left(\mathrm{Nt}^{\wedge} 2 \mathrm{pq}\right) /\left(\mathrm{d}^{\wedge} 2(\mathrm{~N}-1)+\mathrm{t}^{\wedge} 2 \mathrm{pq}\right)$ and the sample size was calculated 347 . In the formula:

- $\mathrm{N}$ : Number of individuals in the target population (3637)

- $\mathrm{n}$ : Number of individuals to be sampled

- p: Prevalence of the case investigated (probability of occurrence) (0.50)

- q: Non-prevalence of the case investigated (probability of non-occurrence) (0.50)

- $\mathrm{t}$ : Theoretical value found from $\mathrm{t}$ table at a particular independent level and identified margin of error was considered 1.96 at $95 \%$ significance level.

- d: Desired level according to the prevalence \pm deviation, 0.05 margin of error ( $5 \%$ deviation)

Random sampling method was used to collect the data. The data of the research was collected by using a data collection form prepared by reviewing the literature by the researchers. Pregnant women who knew Turkish and had no problems with verbal communication were included in the study. The data was collected by face to 
face interview in the maternity clinic by the researchers. The participation in the study was on voluntary basis, and the purpose of the study and participation on voluntary basis were explained to the pregnant women. Pregnant women who accepted to participate were applied data collection form. SPSS package software was used to analyze the study data. Descriptive statistics (number and percentage) were used to evaluate the data.

It was paid attention to comply with ethical principles in all stages of the study. Before starting the study, the ethics committee approval (no. 2014.12.05) was obtained from Ethics Committee of Nevşehir Hacı Bektaş Veli University and written approval was obtained from Nevşehir State Hospital of Nevşehir Public Hospital Association. Also, before filling data forms, the verbal consents of pregnant women were obtained after informing them about the purpose of the research.

\section{Results}

Of the pregnant women who participated in the study, $24.2 \%$ were between 21 and 25 years old, $41.8 \%$ were living in city center, $34.6 \%$ were graduated from secondary school, $80.7 \%$ were housewives, $50.4 \%$ had income equal to their expenses, and $43.8 \%$ had husbands who were workers. It was also found that it was first pregnancy in $27.7 \%$ of the pregnant women, $35.4 \%$ of them had 4 and more pregnancy, $11 \%$ of them had preterm labor, $27.7 \%$ of them had the history of miscarriage/curettage, and $3.5 \%$ of them had stillbirth.

It was found that $4.9 \%$ of the pregnant women had thyroid disorder, all pregnant women who had thyroid disorder had hypothyroidism ( $\mathrm{n}=17)$, and $9.8 \%$ of them had a history of thyroid disorder in their families and the mothers of $76.5 \%$ of these pregnant women had a history of disease.

Of the pregnant women who participated in the study, $35.7 \%$ stated that they did not know the importance of protecting themselves against iodine deficiency and $65.7 \%$ stated that they did not know the necessity of using iodized salt during pregnancy. Of the pregnant women who knew the necessity of using iodized salt during pregnancy, $43.6 \%$ stated that it was necessary for the brain development of baby. Although 55.9\% of the pregnant women reported that they were using iodized salt, $62 \%$ of them said that they did not pay attention if the salt they purchase is iodized or not. Also, $40.2 \%$ of the pregnant women using iodized salt said that they did not know why they need to use iodized salt (Table 1).
While $45.9 \%$ of the pregnant women using iodized salt kept it in glass jar with lid and $69.6 \%$ of them paid attention to keep iodized salt away from the sunlight, only $46.1 \%$ of them could properly explain why it should be kept away from sunlight (as vitamin/mineral would be lost, chemical structure of iodine would be damaged) (Table 2).

Table 1. The distribution of pregnant women in terms of iodized salt use $(n=347)$.

\begin{tabular}{|c|c|c|}
\hline & $\mathbf{n}$ & $\%$ \\
\hline \multicolumn{3}{|l|}{ Use of iodized salt } \\
\hline I use & 194 & 55.9 \\
\hline I do not use & 153 & 44.1 \\
\hline \multicolumn{3}{|c|}{ Paying attention to purchase iodized salt } \\
\hline Yes & 132 & 38.0 \\
\hline No & 215 & 62.0 \\
\hline \multicolumn{3}{|l|}{ Salt type used at home } \\
\hline Rock salt & 144 & 41.5 \\
\hline Sea salt & 7 & 2.0 \\
\hline Himalayan salt & 2 & 0.6 \\
\hline lodized salt & 194 & 55.9 \\
\hline \multicolumn{3}{|c|}{ The reason for using iodized salt $(n=194)$} \\
\hline I do not know why I have to use it & 78 & 40.2 \\
\hline I believe that it is healthier & 67 & 34.5 \\
\hline Because it is beneficial & 32 & 16.5 \\
\hline Because it is good for goiter & 17 & 8.8 \\
\hline \multicolumn{3}{|c|}{ The frequency of using iodized salt $(n=194)$} \\
\hline Always & 142 & 73.2 \\
\hline From time to time & 48 & 24.7 \\
\hline I started to use during pregnancy & 4 & 2.1 \\
\hline
\end{tabular}

Table 2. The distribution of iodized salt according to proper using / keeping conditions among pregnant women using iodized salt.

\begin{tabular}{|c|c|c|}
\hline & $\mathbf{n}$ & $\%$ \\
\hline \multicolumn{3}{|l|}{ Location where iodized salt is kept $(n=194)$} \\
\hline Original packaging & 6 & 3.1 \\
\hline Glass jar with lid & 89 & 45.9 \\
\hline Light-proof jar with lid & 85 & 43.8 \\
\hline Open salt shaker & 14 & 7.2 \\
\hline \multicolumn{3}{|c|}{ Paying attention to keep iodized salt away from sunlight $(n=194)$} \\
\hline Pays attention & 135 & 69.6 \\
\hline Does not pay attention & 59 & 30.4 \\
\hline \multicolumn{3}{|c|}{ The reason for keeping iodized salt away from sunlight $(n=194)$} \\
\hline No reason & 27 & 13.9 \\
\hline I do not know & 37 & 19.1 \\
\hline To keep away from moisture & 36 & 18.6 \\
\hline Because vitamin/mineral would be lost & 18 & 9.3 \\
\hline Because chemical structure of iodine would be damaged & 68 & 35.0 \\
\hline Its odor would change under sunlight & 8 & 4.1 \\
\hline \multicolumn{3}{|l|}{ Time to add salt into meals $(n=347)$} \\
\hline After the meal is cooked & 58 & 16.7 \\
\hline During the cooking & 289 & 83.3 \\
\hline
\end{tabular}


Of the pregnant women, $69.7 \%$ use tap water as drinking water, $92.5 \%$ use tap water in their meals while $72.1 \%$ do not know iodine-rich foods. Of those who know iodine-rich foods, $79.4 \%$ believe that sea products are iodine-rich, but $73.2 \%$ of the pregnant women do not pay attention to consume iodine-rich foods during pregnancy (Table 3).

On the other hand, it was found that the pregnant women rarely consume foods which are poor in iodine (kale, cabbage, turnip, white turnip), and only consume milk and dairy products more frequently as iodine-rich foods.

Of the pregnant women, $31.4 \%$ stated that they were informed about the use of iodized salt during pregnancy and $67.9 \%$ of these pregnant women were informed by healthcare professionals. Also, $58.7 \%$ of the pregnant women stated that they were informed about the benefits of iodine on health.

\section{Discussion}

Preventing iodine deficiency is important to protect the health of mother and baby. Using iodized salt has an important role on the prevention of iodine deficiency diseases. ${ }^{[22]}$ The Communique of Turkish Food Codex on Edible Salt was published in $1998 .{ }^{[23]}$ With this communique, it was obliged to enrich table salt by iodine in Turkey. In our study, $55.9 \%$ of the pregnant women stated that they use iodized salt. It is seen in the studies on the use of iodized salt during pregnancy that the rate of using iodized salt varies between $26.1 \%$ and $96 \%$ among the pregnant women. ${ }^{[3,21,24-28]}$ In our study, we found that almost half of the pregnant women were not using iodized salt. This result of our study is important in terms of showing the fact that the knowledge on the use of iodized salt by pregnant women is insufficient or these pregnant women are not aware of its importance.

In our study, $51 \%$ of the pregnant women stated that they are using iodized salt as it is more beneficial and healthier. In the study of Şenbayram, 50\% of pregnant women explained the reason for using iodized salt as it is beneficial and healthy. ${ }^{[3]}$ Seventy-seven percent of the pregnant women in the study of Kirkizoğlu and Pekcan ${ }^{[2]}$ and $93.9 \%$ of the pregnant women in the study of Köksal and Pekcan ${ }^{[26]}$ stated that they did not know why they should use iodized salt. In our study, almost half of the pregnant women use iodized salt and half of those using iodized salt do not know why they use it. This result
Table 3. The distribution of pregnant women in terms of iodine intake and nourishment characteristics ( $n=347)$.

\begin{tabular}{|c|c|c|}
\hline & $\mathbf{n}$ & $\%$ \\
\hline \multicolumn{3}{|l|}{ Using tap water $(n=347)$} \\
\hline Bottle water & 87 & 25.1 \\
\hline Tap water & 242 & 69.7 \\
\hline Purified water & 18 & 5.2 \\
\hline \multicolumn{3}{|l|}{ Water added into meals $(n=347)$} \\
\hline Bottle water & 8 & 2.3 \\
\hline Tap water & 321 & 92.5 \\
\hline Purified water & 18 & 5.2 \\
\hline \multicolumn{3}{|c|}{ The knowledge about iodine-rich foods $(n=97)$} \\
\hline She knows & 97 & 27.9 \\
\hline She does not know & 250 & 72.1 \\
\hline \multicolumn{3}{|c|}{ The foods known as iodine-rich $(n=97)$} \\
\hline Dairy products & 7 & 7.2 \\
\hline Sea products & 77 & 79.4 \\
\hline Green vegetables & 8 & 8.2 \\
\hline Legumes & 4 & 4.1 \\
\hline Red meat and meat products & 1 & 1.0 \\
\hline \multicolumn{3}{|c|}{ Paying attention to consume iodine-rich foods during pregnancy $(n=347)$} \\
\hline Yes & 93 & 26.8 \\
\hline No & 254 & 73.2 \\
\hline \multicolumn{3}{|c|}{ lodine-rich foods consumed by pregnant women $(n=93)$} \\
\hline Dairy products & 6 & 6.5 \\
\hline Sea products & 75 & 80.6 \\
\hline Green vegetables & 8 & 8.6 \\
\hline Legumes & 3 & 3.2 \\
\hline Red meat and meat products & 1 & 1.1 \\
\hline
\end{tabular}

shows that pregnant women have insufficient knowledge about the use of iodized salt. Iodine deficiency is a significant condition for the health of mother, fetus and newborn. Iodine deficiency may cause insufficient fertilization, preeclampsia, postpartum hemorrhage, anemia, and miscarriage risk in women, and low birth weight, stillbirth, congenital anomalies, microcephaly, cretinism and similar outcomes in fetuse.s It may also cause goiter and hypothyroidism in the newborn. ${ }^{[9]}$ In our study, $70.9 \%$ of the pregnant women stated that they did not know the importance of protection against iodine deficiency and they did not do anything for it. This rate was $12 \%$ in the study of Şenbayram. ${ }^{[3]}$ Compared to the study of Syenbayram, we believe that this difference in the rates might be because of the low education and employment levels of women in our study.

Iodized salt should be kept in a cool, dry environment without light and in dark colored glass containers in order to prevent iodine loss. ${ }^{[30]}$ In our study, $45.9 \%$ of the pregnant women expressed that they are keeping salt in glass jar with lid. While $71.6 \%$ of the pregnant 
women in the study of Akın were keeping salt in glass jar, ${ }^{[2]} 76 \%$ of the pregnant women in the study of Özkan were keeping salt in a cool, closed environment without any sunlight. ${ }^{[28]} 19.1 \%$ of the pregnant women in the study of Şenbayram and $13.9 \%$ of the pregnant women in the study of Ulu stated that they were keeping salt in light-proof jars which are the ideal containers. ${ }^{[3,27]}$ In our study and many other studies, we can see that most of the pregnant women do not keep salt under proper conditions. Iodine loss occurs in salts which are not kept under proper conditions, and it results in the problems associated with iodine deficiency even iodized salt is used.

Iodine is a substance which is affected by heat, moisture and other climatic conditions. Since iodized salt loses approximately $50 \%$ of its content when cooked, it is recommended to add iodized salt after the meal is prepared. ${ }^{[31]}$ In our study, $83.3 \%$ of the pregnant women reported that they add salt into the meal during cooking. Of the pregnant women, $67.7 \%$ in the study of $\mathrm{Ulu}^{[27]}$ and $91.5 \%$ in the study of Özkan ${ }^{[28]}$ stated that they add salt into meal before starting to cook. In the study of Şenbayram, $16.3 \%$ of the pregnant women said that they add salt into the pot after the meal is cooked. ${ }^{[3]} \mathrm{It}$ is seen both in our study and other studies conducted on this topic that iodized salt is not added during the recommended times. The presence of iodine deficiency despite the high consumption of salt in Turkey shows that the salt used is not iodized and/or individuals have insufficient knowledge about the proper use of iodized salt.

Iodine is a trace element which penetrates into the structure of thyroid hormones and is essential for the normal activity of thyroid hormones that are necessary for the normal growth and neurological development of fetus during the pregnancy. ${ }^{[3]}$ According to the report of WHO/ICCIDD in 2007, the best method for iodine replacement in pregnant women is to iodize salt. ${ }^{[16]}$ Turkey is a region with moderate/severe level of iodine deficiency and endemic goiter. ${ }^{[2]}$ Iodine need increases during pregnancy, and iodine deficiency during pregnancy may disrupt thyroid hormone production, affect physical and mental development of fetus negatively, and increase mortality risk of newborn. ${ }^{[1]]}$ In our study, $25.4 \%$ of the pregnant women expressed that the use of iodized salt during pregnancy is necessary and $8.8 \%$ of them associated this necessity with thyroid gland.

In our study, $4.9 \%$ of the pregnant women had hypothyroidism. Bostancı and Taşkesen reported in their study conducted on pregnant women that the rate of hypothyroidism was $2.8 \% .^{[4]}$ This rate was $15.8 \%$ in the study of Güzel et al. ${ }^{[5]} 2.8 \%$ in the study of Şenbayram, ${ }^{[3]}$ and $1.8 \%$ in the study of Fadayev et al. ${ }^{[33]}$ According to 2017 report of Turkish Endocrinology and Metabolism Society, hypothyroidism prevalence during pregnancy was $0.3-0.5 \%$ for overt hypothyroidism and $2-3 \%$ for sub-clinical hypothyroidism. ${ }^{[2]}$ Hypothyroidism rate of pregnant women in our study was higher than other studies. The iodine concentration of local drinking water is also another indicator of the iodine content of soil. While the iodine content in iodine-poor regions is usually below $2 \mu \mathrm{g} / \mathrm{L}$, it is $9.0 \mu \mathrm{g} / \mathrm{L}$ and above in the regions which are not iodine-poor. ${ }^{[2]}$ The Public Health Laboratory of the region where the study was conducted reports that the tap water of the city has insufficient iodine. In our study, $92.5 \%$ of the pregnant women stated that they use tap water. Of the pregnant women, $46.6 \%$ in the study of Akın, $50.5 \%$ in the study of Özkan and $37.8 \%$ in the study of Ulu were using tap water. ${ }^{[2,27,28]}$ Absence of iodine in the tap water is important in terms of revealing iodine deficiency and iodine-related problems. This finding of the study highlights the importance of planning and providing training about the use of iodized salt to people who live in iodine-poor regions. The iodine need of fetus is met by maternal iodine transferred transplacentally. ${ }^{[34]}$ Iodized salt, sea products and particularly fish, milk and dairy products are the most important iodine resources. ${ }^{[35]}$ The rate of the cases consuming dairy products daily is $56.5 \%$ in our study. According to the results of 2016 Turkish Nourishment and Health Survey (TBSA), the rate of those drinking milk daily was $28.4 \% .{ }^{[17]}$ Yavuz and Aykut found in their study that $48.8 \%$ of the pregnant women were consuming appropriate amounts of milk and dairy products. ${ }^{[36]}$ While $82.9 \%$ of the pregnant women in the study of Noğay were consuming milk, ${ }^{[37]}$ this rate was $69.6 \%$ in the study of Akın. ${ }^{[25]}$ The studies carried out have similar results compared to our study, and the rate of pregnant women consuming milk and dairy products is insufficient. Consuming insufficient amount of milk and dairy products is a significant indicator showing insufficient intake of iodine resources.

Antithyroid compounds in some foods may cause iodine deficiency by blocking iodine transfer in thyroid gland. The most important resources for antithyroid compounds are cauliflower, cabbage, Brussels sprout, turnip, white turnip and similar vegetables. ${ }^{[27]}$ The pregnant women in our study rarely consume these vegeta- 
bles. In the study of Akin, the authors reported that $45.1 \%$ of the pregnant women consume cabbage, $13.4 \%$ of them consume white turnip and $38.2 \%$ of them consume turnip. ${ }^{[25]}$ Excessive consumption of these vegetables cause insufficient intake or use of iodine by the body; however, the consumption of these vegetables is not considered as risky as causing iodine deficiency in terms of consumption frequency. Iodine mainly exists in the soil; most of the iodine in the world is taken from the surface by glaciers, snow and rains and carried into oceans by winds, rivers and floods. Therefore, seaweeds and sea products are rich in iodine. ${ }^{[3]}$ In our study, $14.1 \%$ of the pregnant women were consuming fish for a few days per week. According to 2010 data of Turkish Nourishment and Health Survey, $79 \%$ of the pregnant women consume fish at least once during their pregnancy. ${ }^{[17]}$ Akın et al. reported in their study that $73.9 \%$ of the pregnant women consume sea products. ${ }^{[25]}$ In the study of Noğay, $87.1 \%$ of the pregnant women were consuming fish and only $52.9 \%$ of them were consuming fish for 1-2 times a week. ${ }^{[37]}$ In the previous studies and our study, it is seen that pregnant women do not consume iodine-rich sea products regularly and sufficiently. Of the pregnant women, only $31.4 \%$ stated that they were informed about the use of iodized salt during pregnancy and $67.9 \%$ of these informed pregnant women received this information from healthcare professionals. In the study of Şenbayram, these rates were $73 \%$ and $37 \%$, respectively. ${ }^{[3]}$ The fact that approximately one third of the pregnant women were informed about the use of iodized salt and two third of informed pregnant women received this information from healthcare professionals indicates that the information they receive may be insufficient and incorrect. The low level of iodized salt use and insufficient level of knowledge about the significance of iodized salt can be explained with the insufficient information received.

\section{Conclusion}

We found in our study that $74.1 \%$ of the pregnant women had no knowledge on iodine deficiency and associated diseases, $35.7 \%$ of them did not know the importance of protection against iodine deficiency, and $65.7 \%$ of them did not know the necessity of using iodized salt during pregnancy. Also, we found that $44.1 \%$ of the pregnant women included in the study did not use iodized salt, $56.2 \%$ of those using iodized salt did not keep it in a proper way, and $16.7 \%$ of them added iodized salt into their meal after prepared. We found that $68.6 \%$ of the pregnant women did not receive information for the use of iodized salt during pregnancy. In conclusion, we found that the use of iodized salt during pregnancy and knowledge on the use of iodized salt are insufficient.

Beginning from the pregestational period, pregnant women and their families should be informed about the use and importance of iodized salt during pregnancy, studies should be planned to determine the knowledge of healthcare professionals about the use of iodized salt, nurses should perform house visits to inform pregnant women and observe the use of iodized salt conditions onsite and repeat their trainings if necessary.

Conflicts of Interest: No conflicts declared.

\section{References}

1. Türkiye Kadın Sağlığı Araştırması. T.C. Sağlık Bakanlığ Sağlık Araştırmaları Genel Müdürlüğü. Ankara; 2014. ISBN: 978-975-590-491-7.

2. Tiroid Hastalıkları Tanı ve Tedavi Kılavuzu. Ankara: Türkiye Endokrinoloji ve Metabolizma Derneği: 2017. s. 114-7.

3. Şenbayram S. Gebeliğin ilk üç ayında olan kadınların iyot eksikliği ve tiroid fonksiyonları açısından değerlendirilmesi. Ankara: Başkent Üniversitesi Tip Fakültesi Aile Hekimliği Anabilim Dalı; 2007.

4. Bostancı MS, Taşkesen F. Gebelikte tiroid fonksiyon bozuklukları ve sonuçlarının değerlendirilmesi. Klinik ve Deneysel Araştırmalar Dergisi 2011;2:196-201.

5. Güzel E, Sivri Aydın D, Çilesiz Göksedef BP, Boran AB. Gebelerde tiroid fonksiyon bozukluğu sıklığı. Perinatoloji Dergisi 2015;23:96-100.

6. Akdemir N, Birol L. Endokrin sistem hastalıkları ve hemşirelik bakımı. İç hastalıkları ve hemşirelik kitabı. Genişletilmiş 2. baskı. Ankara: Sistem Ofset; 2005. s. 683.

7. Ataş A, Çakmak A, Karazeybek H. Konjenital hipotiroidizm. Journal of Current Pediatrics 2007;5:70-6.

8. Tazegül A, Şimşek B. Gebelikte tiroid hastalıkları. Selçuk Tip Dergisi 2010;26:63-7.

9. Aykut M. Toplum Beslenmesi. Öztürk Y, Günay O, editörler. Halk sağlı̆̆ı. Genel bilgiler. Kayseri: Erciyes Üniversitesi Yayınları; 2011. s. 1247-417.

10. Zimmermann MB, Jooste PI, Pandav CS. Iodine deficiency disorders. Lancet 2008;372(9645):1251-62.

11. Erbaş T. İyot eksikliği ve guatr. Atabey E., editör. Hacettepe Ü. Tip Fak. Endokrinoloji Uluslararası Katılımlı Tibbi Jeoloji Sempozyumu Kitabı. Ankara; 2008. s. 94-5.

12. Haddow JE, Palomaki GE, Allan WC, Williams JR, Knight GJ, Gagnon J, et al. Maternal thyroid deficiency during pregnancy and subsequent neuropsychological development of the child. N Engl J Med 1999;341:549-55. 
13. Yordam N, Çalıkoğlu AS, Hatun Ş, Kandemir N, Oğuz H, Teziç T, et al. Screening for congenital hypothyroidism in Turkey. Eur J Pediatr 1995;154:614-6.

14. MacGillivray M. Congenital hypothyroidism, In: Pescovitz OE, EA, editor. Pediatric endocrinology. Philadelphia, PA: Lipincott Williams and Wilkins; 2004. p. 490-507.

15. Cinaz P, Yeşilkaya E, Acar D, Bideci A, Çamurdan O, Ayvalı E. Yenidoğan konjenital hipotiroidizm tarama sonuçlarının değerlendirilmesi. İstanbul Tip Fakültesi Dergisi 2008;71: $78-83$.

16. Assessment of iodine deficiency disorders and monitoring their elimination. A guide for programme managers. Geneva: World Health Organization; 2007.

17. Türkiye Beslenme ve Sağlık Araştırması (TBSA) 2010. Ankara: Hacettepe Üniversitesi Sağlık Bilimleri Fakültesi Beslenme ve Diyetetik Bölümü; 2014. s. 53.

18. Oguz Kutlu A, Kara C. Iodine deficiency in pregnant women in the apparently iodine-sufficient capitalcity of Turkey. Clin Endocrinol (Oxf) 2012;77:615-20.

19. Egri M, Ercan C, Karaoglu L. Iodine deficiency in pregnant women in eastern Turkey (Malatya Province): 7 years after the introduction of mandatory table salt iodization. Public Health Nutr 2009;12:849-52.

20. Kurtoğlu S, Akcakus M, Kocaoglu C, Gunes T, Budak N, Atabek ME, et al. Iodine status remains critical in mother and infant in Central Anatolia (Kayseri) of Turkey. Eur J Nutr 2004;43:297-303.

21. Anaforoğlu İ, Algün E, İnceçayır Ö, Topbaş M, Erdoğan MF. Iodine status among pregnant women after mandatory salt iodisation. Br J Nutr 2016;115:405-10.

22. Sağlık Bakanlığı Sağlık Eğitimi Genel Müdürlüğü. Gebelik ve emziklilik döneminde beslenme. Beslenme modülleri. Eğitimciler için eğitim rehberi. Ankara: İlkay Ofset Matbaacılık; 2008. s. 44.

23. T.C Resmi Gazete. Sayı: 23397. s. 29-31.

24. Çakır Ç, Teziç T, Zorlu P, Oğuz Kutlu A, Fırat S. Anne idrar iyot düzeyleri ile anne kanında ve kordon kanında TSH, ST4 düzeylerinin karşılaştırılması. Türkiye Klinikleri Journal of Pediatrics 2002;11:126-30.

25. Akın R. Gebe kadınlarda trimesterlere göre idrarda iyot düzeyleri ve beslenme durumlarının değerlendirilmesi.
Yüksek Lisans Tezi, Selçuk Üniversitesi Sağlık Bilimleri Enstitüsü, Hemşirelik Anabilim Dalı, Konya, 2012.

26. Köksal E, Pekcan G. Gebe kadınlar ile yeni doğanlarının idrarla iyot atım durumlarının ilişkisi. Sürekli Tıp Eğitimi Dergisi 2009;18:68-70.

27. Ulu H. Gebe kadınlarda ve yenidoğan bebeklerinde idrar iyot düzeyleri ve tiroid fonksiyon testleri sonuçlarının değerlendirilmesi. Uzmanlık Tezi, Selçuk Üniversitesi Tıp Fakültesi Aile Hekimliği Anabilim Dalı, Konya, 2012.

28. Özkan P. Aydın ilindeki yenidoğan ve annelerinde idrar iyot düzeyleri ve tiroid fonksiyon testleri. Uzmanlık Tezi, Adnan Menderes Üniversitesi Tip Fakültesi Çocuk Sağlı̆̆1 ve Hastalıkları Anabilim Dalı, Aydın, 2008.

29. Kirkizoğlu E, Pekcan G. Ankara ili Çubuk ilçesi Kuruçay ve Kışlacık köylerinde iyot yetersizliği hastalığı prevalansı, idrarla iyot atımı ve iyotlu tuz kullanımı. Beslenme ve Diyet Dergisi 2001;30:12-8.

30. Ayaz A. Tuz tüketimi ve sağlık. Hacettepe ÜniversitesiSağlık Bilimleri Fakültesi Beslenme ve Diyetetik Bölümü, Ankara: Klasmat Matbaacilık; 2008. s. 18.

31. Baysal A. Beslenme. 10. baskı. Ankara: Hatiboğlu Yayınevi; 2004. s. 268-75.

32. Alvarez-Pedrerol M, Ribas-Fitó N, García-Esteban R, Rodriguez A, Soriano D, Guxens M, et al. Iodine sources and iodine levels in pregnant women from an area without known iodine deficiency. Clin Endocrinol (Oxf) 2010;72:816.

33. Fadayev V, Lesnikova S, Melnichenko G. Prevalence of thyroid disorders in pregnant women with mild iodine deficiency. Gynecol Endocrinol 2003;17:413-8.

34. Kurtoğlu S. İyot eksikliği sorununun değerlendirilmesi ve çözüm yolları. Türk Pediatri Arşivi 1997;32:4-13.

35. Aile ve Tüketici Hizmetleri. Sağlıklı yaşam ve besinler. Ankara: Milli Ĕ̆itim Bakanlı̆̆ı; 2011. s. 30.

36. Yavuz S, Aykut M. Kayseri Melikgazi Eğitim Araştırma Sağlık Grup Başkanlığı bölgesinde gebe kadınların gebelikte beslenme konusundaki bilgi düzeyleri ve beslenme durumu. Sağlık Bilimleri Dergisi 2014;23:10-20.

37. Noğay NH. Gebe kadınların beslenme durumunun değerlendirilmesi. Elektronik Meslek Yüksekokulları Dergisi 2011;1: $51-7$. 